\title{
Rubus apetalus (Rosaceae) improves spermatozoa characteristics, antioxidant enzymes and fertility potential in unilateral cryptorchid rats
}

Désiré Alumeti Munyali 1,2, Aimé Césaire Tetsatsi Momo', Georges Romeo Bonsou Fozin', Patrick Brice Deeh Defo', Yannick Petnga Tchatat ${ }^{1}$, Boris Lieunang ${ }^{1}$ and Pierre Watcho ${ }^{1 *}$

\begin{abstract}
Background: Cryptorchidism (CPT) is an important cause of male infertility. Rubus apetalus is a medicinal plant with a powerful antioxidant potential. We investigated the effects of aqueous and methanolic extracts of $R$. apetalus on spermatozoa parameters, antioxidant enzymes and fertility potential of rats with experimental unilateral CPT.

Method: Normal $(n=15)$, sham-operated $(n=15)$ and cryptorchid rats $(n=80$; distributed into 16 groups of 5 rats/ group) were treated for 2,4 or 8 weeks with either distilled water $(10 \mathrm{ml} / \mathrm{kg} /$ day), vitamin $E(75 \mathrm{mg} / \mathrm{kg} /$ day), aqueous or methanolic extract of $R$. apetalus (12 and $60 \mathrm{mg} / \mathrm{kg}$ ). Sex organ weights, spermatozoa parameters, testicular proteins, sex hormones, fertility potential, morphometric characteristics of testis and oxidative stress markers were measured.

Results: CPT significantly $(p<0.05-0.001)$ decreased testicular and epididymal weights, spermatozoa density, spermatozoa motility, spermatozoa normality, testicular proteins, LH, FSH and testosterone concentrations. In cryptorchid rats, peri-vascular fibrosis significantly increased $(p<0.001)$, while diameter of the seminiferous tube, germ cell thickness, gestation index and fertility index decreased when compared to control. Additionally, CPT induced oxidative stress by increasing lipid peroxidation and by reducing superoxide dismutase and catalase activities. These alterations were corrected by $R$. apetalus. For instance, a significantly increase $(p<0.05-0.001)$ in spermatozoa motility, normality, viability and density after 2,4 and 8 weeks of treatment was noticed. R. apetalus also increased $(p<0.05-0.001)$ testicular proteins, gestation index (90-100\%) and fertility index (90-100\%), compared to the untreated cryptorchid rats.
\end{abstract}

Conclusion: $R$. apetalus boosts fertility potential in cryptorchid rats and could be considered as a promising alternative agent for the management of infertility associated with CPT.

Keywords: Cryptorchidism, Rubus apetalus, Oxidative stress, Fertility, Rat

\footnotetext{
*Correspondence: pwatcho@yahoo.fr; pierre.watcho@univ-dschang.org

'Research Unit of Animal Physiology and Phytopharmacology (URPAP),

Faculty of Science, University of Dschang, Dschang, Box 67, Dschang,

Cameroon

Full list of author information is available at the end of the article
}

(c) The Author(s). 2020 Open Access This article is licensed under a Creative Commons Attribution 4.0 International License, which permits use, sharing, adaptation, distribution and reproduction in any medium or format, as long as you give appropriate credit to the original author(s) and the source, provide a link to the Creative Commons licence, and indicate if changes were made. The images or other third party material in this article are included in the article's Creative Commons licence, unless indicated otherwise in a credit line to the material. If material is not included in the article's Creative Commons licence and your intended use is not permitted by statutory regulation or exceeds the permitted use, you will need to obtain permission directly from the copyright holder. To view a copy of this licence, visit http://creativecommons.org/licenses/by/4.0/ The Creative Commons Public Domain Dedication waiver (http://creativecommons.org/publicdomain/zero/1.0/) applies to the data made available in this article, unless otherwise stated in a credit line to the data. 


\section{Résumé}

Contexte et justificatif: La cryptorchidie (CPT) est. une importante cause de l'infertilité masculine dans le monde. Rubus apetalus est. une plante médicinale au potentiel antioxydant avéré. L'objectif de ce travail était d'évaluer les effets des extraits aqueux et méthanolique de $R$. apetalus sur les paramètres spermatiques, les enzymes antioxydantes et le potentiel de fertilité des rats à CPT unilatérale.

Méthode: Les rats normaux $(n=15)$, simulés $(n=15)$ et cryptorchides $(n=80$; répartis en 16 groupes de 5 rats/groupe) ont été traités pendant 2, 4 ou 8 semaines avec de l'eau distillée $(10 \mathrm{ml} / \mathrm{kg} / \mathrm{jour})$, la vitamine $\mathrm{E}$ ( $75 \mathrm{mg} / \mathrm{kg} / \mathrm{jour}$ ) ou l'extrait aqueux ou méthanolique de $R$. apetalus (12 et $60 \mathrm{mg} / \mathrm{kg}$ ). La masse des organes sexuels, les caractéristiques spermatiques, les marqueurs du stress oxydatif, les hormones sexuelles, l'histomorphométrie testiculaire et la fertilité ont été mesurés au terme des traitements.

Résultats: La CPT a significativement diminué $(p<0,05-0,001)$ la masse testiculaire et épididymaire du côté cryptorchide. Le même constat était fait par rapport à la densité, à la motilité, à la normalité spermatique ainsi que les protéines testiculaires et les hormones sexuelles (LH, FSH et testostérone plasmatiques). Chez les rats cryptorchides, la fibrose péri-vasculaire a augmenté de manière significative $(p<0,001)$ tandis que le diamètre des tubes séminifères, l'épaisseur des cellules germinales, l'indice de gestation et l'indice de fertilité ont diminué par rapport au témoin. De plus, le CPT a induit un stress oxydatif caractérisé par la peroxydation lipidique et la réduction de l'activité des enzymes antioxydantes (SOD et catalase). Ces altérations ont été corrigées par $R$. apetalus. Une augmentation significative $(p<0,05-0,001)$ des paramètres spermatiques, des protéines testiculaires et des hormones sexuelles a été notée après 2,4 et 8 semaines de traitement aux extraits de plante. $R$. apetalus a par ailleurs normalisé l'activité des enzymes antioxydantes et augmenté l'indice de gestation (90-100\%) et l'indice de fertilité (90-100\%) par rapport aux rats cryptorchides non traités.

Conclusion: $R$. apetalus augmente le potentiel de fertilité chez les rats cryptorchides et pourrait être une alternative prometteuse pour la prise en charge de l'infertilité masculine due à la cryptorchidie.

Mots-clés: Cryptorchidie, Rubus apetalus, Stress oxydatif, Fertilité, Rat

\section{Introduction}

Cryptorchidism (CPT) is a boy-congenital malformation characterized by the absence of one (unilateral CPT) or both (bilateral CPT) testes in the scrotum [1,2]. Evidence from literature indicates that unilateral $\mathrm{CPT}$ is more frequent than bilateral CPT [3, 4]. Among unilateral CPT cases, right unilateral $\mathrm{CPT}$ is the more expressed [5-7]. CPT impairs testicular function (mainly due to high temperature) and contributes to male infertility [8]. Although the etiology of this disease is unclear, genetic factors, environmental pollution, nutrition and lifestyle are the main causes of CPT. In the testes of patients with $\mathrm{CPT}$, the integrity of the blood-testis-barrier is compromised due to high temperature [9]. Indeed, high scrotal temperature induces lipid peroxidation, overproduction of reactive oxygen species (ROS) and decreases antioxidant enzymes (catalase, superoxide dismutase, glutathione peroxidase), leading to germ cells death and infertility $[10,11]$. CPT-induced infertility is characterized by a decrease in spermatozoa motility and azoospermia due to the destruction of germ cells and apoptosis [12].

Treatment of CPT is essentially surgical [7] and based on the repositioning of the cryptorchid testis in the normal position (inside the scrotum) in order to protect it against high temperature and oxidative stress [13-15].
Antioxidant compounds such as vitamin $\mathrm{E}$ are also used as adjuvant treatment to control apoptosis of the germ cells by decreasing oxidative stress which is the main cause of the detrimental effects of CPT [16]. These treatment options are expensive and not accessible to low income population. The effectiveness of some medicinal plants in the management of CPT has been reported. For example, Moringa oleifera $[17,18]$ improves spermatozoa parameters in cryptorchid rats through its powerful antioxidant potential; Cuscuta chinensis decreases the germ cell apoptosis in unilateral cryptorchid rats by improving the antioxidant enzymes and regulating the expression of Bax, Bcl-2 and, cleaved caspase 3 [19].

Rubus apetalus, one of such plants, is an annual scrambling shrub from the Rosaceae family. This tropical plant has a cluster of stems from a woody rootstock and can grow to around $150 \mathrm{~cm}$ tall [20]. Its fruits are used as a local food, though the plant is sometimes cultivated in gardens [21, 22]. A decoction of the ripe fruit is mixed with sugar and used to treat anemia while an infusion of the leaves is used for the management of diabetes mellitus [23]. R. apetalus is also used as fertility booster [24], anti-venom [25], anti-fungi [20], and anti-bacteria [26]. Moreover, the in vitro $[27,28]$ and in vivo antioxidant potentials of $R$. Apetalus have been reported and could be justified by its contents in bioactive compounds such 
as saponins, alkaloids, flavonoids, tannins, triterpenoids and vitamins [23]. Since oxidative stress is considered as the main pathway in the harmful effects of CPT, we hypothesized that the powerful antioxidant potentials of $R$. Apetalus may prevent testicular damages and consequently improve fertility. The present study was therefore undertaken to investigate the pharmacological effects of the aqueous and methanolic extracts of $R$. apetalus on some reproductive (sex organ weights, spermatozoa characteristics, testicular proteins, sex hormones, fertility potential and morphometric characteristics of testis) and metabolic (oxidative stress-related biochemical markers) parameters in rats with right unilateral CPT.

\section{Materials and methods Plant collection}

Rubus apetalus (Rosaceae) leaves were harvested in February 2018 in Katana, East Region of Democratic Republic of Congo. The plant was identified by an ethnobotanist (Mr. Balagizi Karhagomba) and authenticated at the Natural Science Research Center (CRSN) under the voucher number 181 . The leaves were shade-dried and transformed into powder with an electric grinder and the powder obtained was used for preparation of extracts.

\section{Preparation of extracts}

Aqueous extract was obtained by infusing $R$. apetalus powder $(5 \mathrm{~g})$ in distilled water $(500 \mathrm{ml})$. After filtration, the filtrate was oven-dried at $40^{\circ} \mathrm{C}$ and $1.054 \mathrm{~g}$ of residue was obtained (extraction yield: $21.08 \%$ ).

For the methanolic extract, $5 \mathrm{~g}$ of $R$. apetalus powder were macerated in $500 \mathrm{ml}$ of methanol (95\%) for $72 \mathrm{~h}$. After filtration, the filtrate was evaporated under reduced pressure using a rotative evaporator and $0.516 \mathrm{~g}$ of residue (methanolic extract) was obtained, giving an extraction yield of $10.32 \%$.

The working solutions of aqueous and methanolic extracts of $R$. apetalus were prepared in distilled water and administered at $12 \mathrm{mg} / \mathrm{kg} /$ day and $60 \mathrm{mg} / \mathrm{kg} /$ day. Doses of plant extracts were chosen from our pilot studies (unpublished data) while that of vitamin E was based from our previous work [29].

\section{Animals}

Young male Wistar rats (8 weeks old; $120-140$ g body weight) were obtained from the animal house of the Faculty of Science, University of Dschang, Cameroon. They were maintained in a standard environment $\left(22-25^{\circ} \mathrm{C}\right.$; $12 \mathrm{~h}$ of light and $12 \mathrm{~h}$ of dark cycle) and had food and water ad libitum. The project was presented and validated by the scientific committee of the Department of Animal Biology, University of Dschang, which follows the internationally accepted standard ethical guidelines for laboratory animal use and care as described in the European Economic Community guidelines; EEC. 2010 Council Directive 2010/63/EU of 22 November 2010 [30].

\section{Induction of cryptorchidism}

Right unilateral CPT is the most common form of CPT $[1,7]$. Right unilateral CPT was induced using the method of Toshihiko et al. [31] with minor modifications. Briefly, the rats were anesthetized with an intraperitoneal administration of diazepam $(10 \mathrm{mg} / \mathrm{kg})$, followed $10 \mathrm{~min}$ later by ketamine $(50 \mathrm{mg} / \mathrm{kg})$. Once the anesthesia was effective, the anterior part of the abdomen was shaved from the right flank to the right ilia fossa in an aseptic condition. An oblique incision (about $2 \mathrm{~cm}$ ) was made, followed by a section of the abdominal muscles, an opening of the parietal peritoneum and, the identification of gubernaculum testis and right inguinal canal. In order to free the bursa, the gubernaculum testis was cut, the right testis was then pulled into the abdomen and the inguinal canal was sutured with cotton thread which prevented further descent of the testis into the scrotum. The surgical procedure ended with repositioning the testis in the abdomen, suturing the peritoneum and muscle before suturing the skin with a cotton thread. After surgery, rats were intramuscularly administered with antibiotic to prevent infections. Cryptorchid rats were used for further experiments 3 days after induction of cryptorchidism $[17,32,33]$.

\section{Experimental protocol}

One hundred ten rats (15 normal, 15 sham operated and 80 cryptorchid rats) were randomly distributed into 22 groups of 5 animals each and orally treated for 2,4 or 8 weeks with either distilled water $(10 \mathrm{ml} / \mathrm{kg} /$ day $)$, vitamin E $(75 \mathrm{mg} / \mathrm{kg} /$ day), aqueous or methanolic extract of $R$. apetalus (12 and $60 \mathrm{mg} / \mathrm{kg}$ ). Only the most effective dose of plant extract $(60 \mathrm{mg} / \mathrm{kg})$ was administered to rats for 8 weeks, the period required for a complete spermatogenic cycle in rats [34] (Fig. 1).

At the end of each treatment period (2, 4 and 8 weeks), testicular and epididymal weights, spermatozoa characteristics, oxidative stress markers, testicular proteins, sex hormones and morphometric characteristics of testis were measured. Moreover, fertility potential was evaluated at the end of the last treatment period (week 8). Indeed, each male was mated with two females of proven fertility. Vaginal smear was daily examined under light microscope (OLYMPUS, X40). The presence of spermatozoa in the vaginal smear was taken as criteria of successful insemination and considered as day 1 of pregnancy. Fertility potential (gestation index, fertility index and litter size) was recorded as described previously $[35,36]$. 

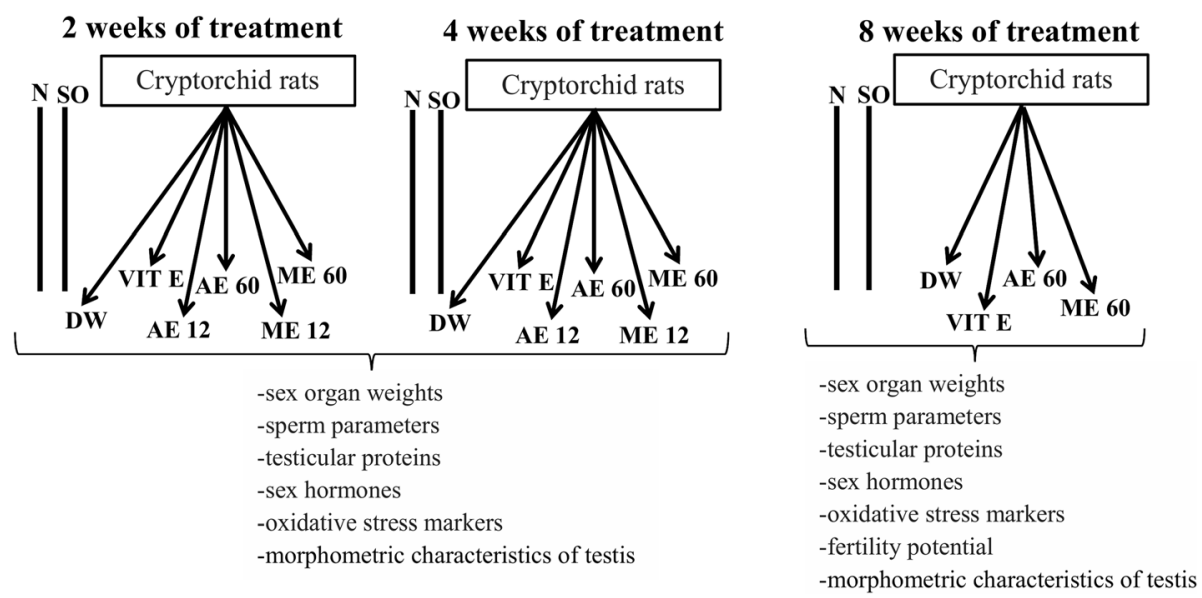

Fig. 1 Experimental protocol of study. Number of rats per group = 5. Abbreviations: N: normal; SO: sham operated; DW: distilled water; Vit E: vitamin E; AE12 / AE60: aqueous extract administered at 12 mg/kg or 60 mg/kg; ME12 / ME60: methanolic extract administered at 12 mg/kg or $60 \mathrm{mg} / \mathrm{kg}$

Tissue preparation and sample analysis

At the end of each treatment period, rats were sacrificed under diazepam/ketamine anaesthesia and testes and epididymis were removed. Relative sex organ weights were calculated using the following formula: Relative sex organ weight $=($ absolute sexual organ weight $/$ body weight $) \times 100$. Half of each epididymis was used for spermatozoa characteristics and the rest for measurement of oxidative stress markers including malondialdehyde (MDA), superoxide dismutase (SOD) and catalase (CAT) and total protein levels. Abdominal artery blood was collected into heparinized tubes and centrifuged (3000 $\mathrm{g}$ for $10 \mathrm{~min}$ ). The plasma obtained was used to quantify sex hormones including luteinizing hormone (LH), follicle stimulating hormone (FSH) and testosterone.

\section{Spermatozoa density and motility}

Immediately after sacrifice, right and left cauda epididymides of each animal were separately minced and thoroughly mixed in $10 \mathrm{ml}$ of warm $\left(36^{\circ} \mathrm{C}\right) 0.9 \% \mathrm{NaCl} .20 \mu \mathrm{l}$ of the mixture were transferred to a Malassez haemocytometer and observed under a light microscope (OLYMPUS, X40). Motile and non-motile spermatozoa were counted in 10 fields and the percentage of motile spermatozoa was determined [29, 37].

For spermatozoa density, a twenty-fold dilution was made by mixing the spermatozoa suspension with $0.9 \%$ $\mathrm{NaCl}$ solution. After shaking, $20 \mu \mathrm{l}$ of the mixture was transferred to a Malassez haemocytometer, observed under a light microscope (OLYMPUS, X40) and, spermatozoa were counted in 10 fields [37].

\section{Spermatozoa viability and morphology}

To determine spermatozoa viability, spermatozoa suspension $(10 \mu \mathrm{l})$ was mixed with eosin $(10 \mu \mathrm{l}$ at $1 \%)$ and nigrosin $(30 \mu \mathrm{l}$ at $5 \%)$ on a slide. The mixture was smeared on the slide and examined under a light microscope (OLYMPUS, 40X). Ten (10) fields on the slide were selected in order to appreciate spermatozoa that were stained pink or red (considered dead), and the unstained spermatozoa (considered viable). The percentage of spermatozoa viability was expressed [37].

The spermatozoa morphology was determined using eosin/nigrosin staining. Eosin $(10 \mu \mathrm{l}$ at $1 \%)$ and nigrosin (30 $\mu \mathrm{l}$ at $5 \%$ ) were added to $10 \mu \mathrm{l}$ of spermatozoa suspension. The prepared smear was used after incubation for $5 \mathrm{~min}$ in an oven $\left(45^{\circ} \mathrm{C}\right)$. Ten (10) fields on the slide were selected in order to appreciate various abnormalities of spermatozoa (head and tail abnormalities, cytoplasmic droplets, tailless spermatozoa) as described previously [37].

\section{Oxidative stress markers and sex hormones}

Testis was crushed in a mortar containing Tris buffer so as to obtain a $10 \%$ homogenate. Supernatant was collected from homogenate and centrifuged $(3000 \mathrm{x} \mathrm{g}$ for $10 \mathrm{~min})$. The supernatant was used for protein, MDA, SOD and catalase analysis. Proteins were measured using a commercial kit (Roche diagnostics cobas c-1111) and protocols were performed according to the manufacturer's instructions. The MDA content was measured using thiobarbituric acid reaction [38]. The tissue SOD and catalase activities were evaluated as described by Dimo et al. [39]. Plasmatic LH, FSH and testosterone levels were quantified using ELISA methods in 
conformity with commercial kit instructions (Accubind, Monobind. Lake Forest, USA) [40, 41].

\section{Statistical analysis}

Data were expressed as mean \pm S.E.M. One-way analysis of variance (ANOVA) followed by Tukey-HSD post-hoc test was used to determine statistical differences among groups. All analyses were performed using Statistica software (version 8.0, StatSoft, Inc., Tulsa, USA). Significance level was set at $p<0.05$.

\section{Results}

\section{Effect of different treatments on the relative weight of} testes and epididymides

The right testis and epididymis weights were significantly $(p<0.001)$ lowered after induction of cryptorchidism, compared to sham operated and normal groups. In each cryptorchid animal administered with vitamin $\mathrm{E}$ or plant extracts, the testis and epididymal weights were significantly increased compared to the right cryptorchid side (Fig. 2a, b).

Effect of different treatments on spermatozoa parameters In the right testis, cryptorchidism induced azoospermia while no significant change was observed in the contralateral testis. Therefore, spermatozoa motility, viability and normality assessment in the right epididymis of cryptorchid animals were impossible.

Azoospermia persisted in the right epididymis of cryptorchid rats after 2,4 and 8 weeks of treatment with the vehicle (distilled water) or dugs (vitamin $\mathrm{E}$ and plant extracts). In the left contralateral epididymis, $R$. Apetalus significantly $(p<0.05-0.001)$ increased the spermatozoa motility (except aqueous extract at $12 \mathrm{mg} / \mathrm{kg}$ ) and spermatozoa with normal morphology (both extracts) after 2, 4 and 8 weeks of treatment. $R$. Apetalus also increased $(p<0.05-0.001)$ the spermatozoa viability (4 weeks: methanolic extract at $60 \mathrm{mg} / \mathrm{kg}$; 8 weeks: aqueous and methanolic extracts at $60 \mathrm{mg} / \mathrm{kg}$ ) and spermatozoa

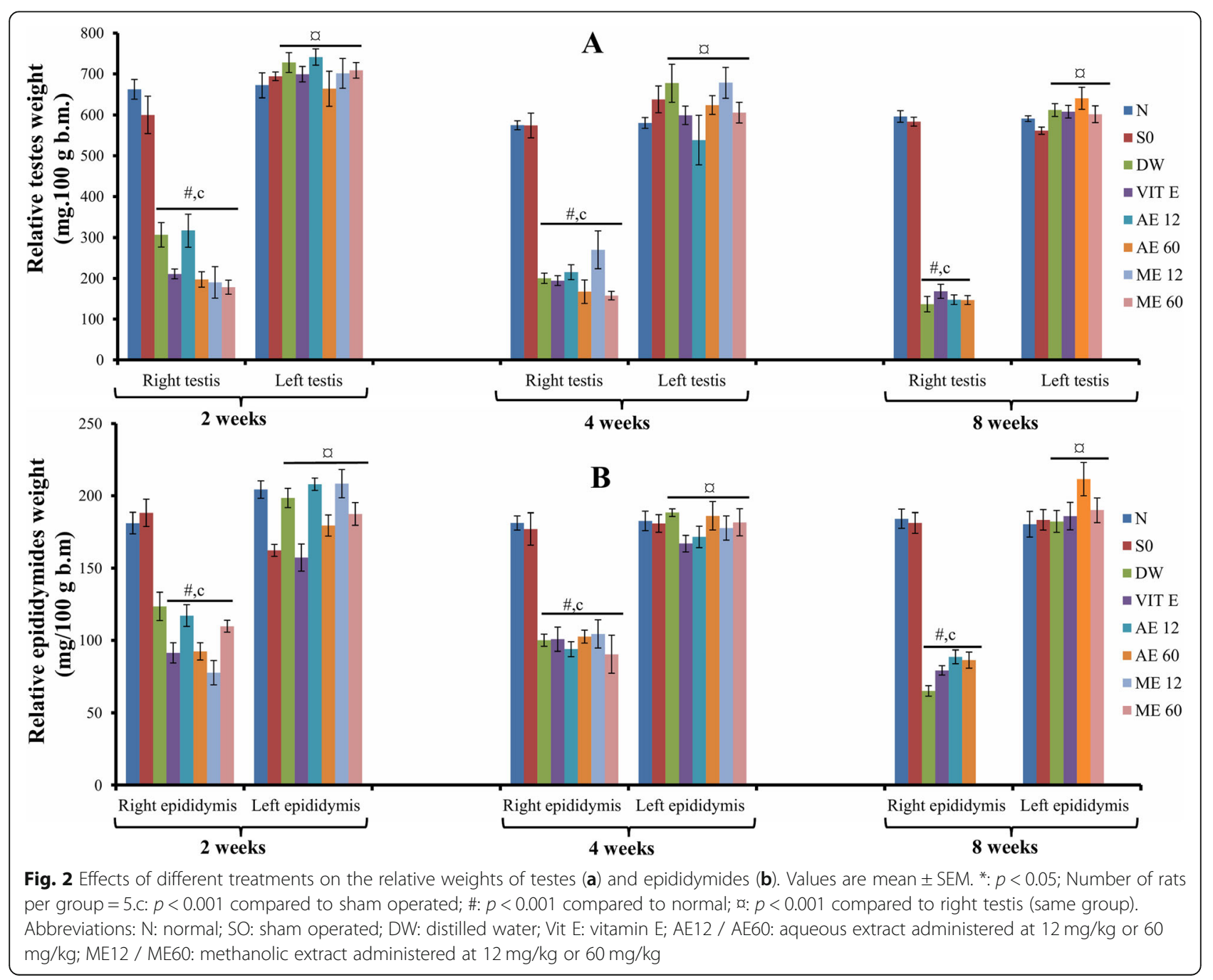


count (4 weeks: methanolic extract at 12 and $60 \mathrm{mg} / \mathrm{kg}$; 8 weeks: aqueous and methanolic extracts at $60 \mathrm{mg} / \mathrm{kg}$ ) compared to untreated cryptorchid rats (DW group). However, at all treatment periods, the methanolic extract $(60 \mathrm{mg} / \mathrm{kg})$ was more effective than the aqueous extract (Table 1).

\section{Effect of different treatments on spermatozoa morphological abnormalities}

No spermatozoa was observed from the cryptorchid testis, whereas from the contralateral testis, an increase in the percentage of sperm with abnormal head, abnormal tail, tailless head and cytoplasmic droplet was recorded when compared to normal and sham operated.

When compared with the untreated cryptorchid rats (DW group), administration of vitamin E or R. Apetalus was followed by a significantly $(p<0.001)$ decrease in the percentage of spermatozoa with abnormal head and abnormal tail after 2, 4 and 8 weeks of treatment. Moreover, $R$. apetalus significantly decreased the percentage of cytoplasmic droplet after 2 weeks (methanolic extract at $60 \mathrm{mg} / \mathrm{kg}$ ), 4 weeks (methanolic extract at $60 \mathrm{mg} / \mathrm{kg}$ ) and 8 weeks (aqueous and methanolic extracts at $60 \mathrm{mg} /$ $\mathrm{kg}$ ) of treatment. The effect of $R$. Apetalus was dosedependent (Table 2).

\section{Effect of different treatments on testicular proteins}

In all untreated cryptorchid rats, the protein concentrations were lowered in the right testis compared to the left testis. Vitamin $\mathrm{E}$ and $R$. apetalus extracts significantly $(p<0.05)$ increased the testicular protein contents (in the right testis) after 2 weeks of treatment. At all

Table 1 Effects of different treatments on sperm parameters

\begin{tabular}{|c|c|c|c|c|c|c|c|c|}
\hline \multicolumn{9}{|c|}{ Sperm parameters } \\
\hline \multirow[t]{2}{*}{ Groups } & \multicolumn{2}{|l|}{ Viability (\%) } & \multicolumn{2}{|c|}{ Sperm count $\left(10^{6} / \mathrm{mL}\right)$} & \multicolumn{2}{|l|}{ Motility (\%) } & \multicolumn{2}{|l|}{ Normality (\%) } \\
\hline & Right testis & Left testis & Right testis & Left testis & Right testis & Left testis & Right testis & Left testis \\
\hline \multicolumn{9}{|l|}{2 weeks } \\
\hline $\mathbf{N}$ & $92.03 \pm 0.5$ & $91.03 \pm 0.6$ & $178.62 \pm 7.00$ & $179.62 \pm 8.00$ & $60.9 \pm 4.05$ & $61.06 \pm 4.65$ & $70.50 \pm 0.87$ & $68.07 \pm 0.94$ \\
\hline so & $89.26 \pm 0.57$ & $88.16 \pm 0.68$ & $113.30 \pm 11.75$ & $114.50 \pm 12.45$ & $66.05 \pm 2.59$ & $67.55 \pm 3.49$ & $65.56 \pm 0.96$ & $64.16 \pm 1.64$ \\
\hline DW & $0 \#, c, p^{, a,}$ & $93.50 \pm 1.42$ & O\#, c, $\mathrm{a}^{, \mathrm{d}}$ & $92.12 \pm 27.29$ & $0 \#, c, a$ & $44.37 \pm 0.83$ & $0 \#, c, a^{, a}$ & $50.85 \pm 2.28$ \\
\hline VIT E & $0 \#, c, p^{, a^{a}}$ & $87.36 \pm 2.47$ & $0 \#, c, a^{, a}$ & $133.75 \pm 15.45$ & O\#, c, , a, & $58.02 \pm 7.49$ & $0 \#, c, a^{, a}$ & $59.7 \pm 2.66^{*}$ \\
\hline AE 12 & $0 \#, c, a^{\alpha}$ & $91.81 \pm 1.60$ & $0 \#, c, p^{, a^{a}}$ & $111.75 \pm 17.44$ & $0 \#, c, x^{, a p}$ & $65.47 \pm 5.85$ & $0 \#, c, x^{, a}$ & $70.95 \pm 1.74^{* * *}$ \\
\hline AE 60 & $0 \#, c, q^{, a}$ & $91.90 \pm 3.53$ & $0 \#, c, a^{, a}$ & $107.75 \pm 13.58$ & $0 \#, c, a^{, a,}$ & $72.08 \pm 4.17^{*}$ & $0 \#, c, a^{, a}$ & $71.11 \pm 1.61^{* * *}$ \\
\hline ME 12 & $0 \#, c, a^{, a p}$ & $90.10 \pm 1.50$ & $0 \#, c, x^{, a}$ & $61.12 \pm 5.92$ & $0 \#, c, p^{, a p}$ & $75.34 \pm 5.75^{*}$ & $0 \#, c, a^{, a}$ & $62.69 \pm 1.08^{* * *}$ \\
\hline ME 60 & $0 \#, c, a^{, i,}$ & $98.90 \pm 1.86$ & $0 \#, c, p^{, a^{n}}$ & $63.50 \pm 4.93$ & $0 \#, c, x^{, x^{x}}$ & $84.01 \pm 2.08^{* * *}$ & $0 \#, c, x^{, a p}$ & $75.04 \pm 1.33^{* * *}$ \\
\hline \multicolumn{9}{|l|}{4 weeks } \\
\hline $\mathbf{N}$ & $93.14 \pm 0.67$ & $91.03 \pm 0.67$ & $156.62 \pm 7.50$ & $157.87 \pm 7.41$ & $70.9 \pm 3.85$ & $71.84 \pm 1.42$ & $\{66.13 \pm 0.87)$ & $67.35 \pm 0.72$ \\
\hline so & $87.56 \pm 0.46$ & $88.16 \pm 0.68$ & $151.20 \pm 9.75$ & $153.12 \pm 3.47$ & $75.05 \pm 2.35$ & $77.43 \pm 2.08$ & $65.06 \pm 1.22$ & $65.46 \pm 1.24$ \\
\hline DW & $0 \#, c, a$ & $81.34 \pm 1.85$ & $0 \#, c, a$ & $88.50 \pm 10.87$ & $0 \#, c, a$ & $65.49 \pm 1.68$ & O\#, c, a & $53.45 \pm 1.29$ \\
\hline VIT E & $0 \#, c, \alpha$ & $87.17 \pm 0.70$ & $0 \#, c, d$ & $108.38 \pm 12.88$ & $0 \#, c, \alpha$ & $74.41 \pm 1.38$ & $0 \#, c, d$ & $64.8 \pm 2.78^{*}$ \\
\hline AE 12 & $0 \#, c, a$ & $84.95 \pm 0.83$ & $0 \#, c, a$ & $74.88 \pm 9.92$ & $0 \#, c, a$ & $72.91 \pm 2.61]$ & $0 \#, c, a$ & $72.54 \pm 1.21^{* * *}$ \\
\hline AE 60 & $0 \#, c, a$ & $86.02 \pm 1.58$ & $0 \#, c, a$ & $102.50 \pm 7.23$ & $0 \#, c, a$ & $82.93 \pm 3.06^{* *}$ & $0 \#, c, a$ & $78.54 \pm 1.82^{* * *}$ \\
\hline ME 12 & O\#, c, a & $84.01 \pm 0.91$ & $0 \#, c, a$ & $135.13 \pm 24.95^{*, \Delta}$ & O\#, c, a & $80.39 \pm 2.90^{*}$ & $0 \#, c, a^{\prime \prime}$ & $51.71 \pm 1.91^{* * *}$ \\
\hline ME 60 & O\#, c, a & $91.34 \pm 4.16^{* *}$ & $0 \#, c, a$ & $144.00 \pm 28.80^{*}, \Delta$ & O\#, c, Q & $85.67 \pm 1.76^{* * *}$ & $0 \#, c, a$ & $79.84 \pm 1.41^{* * *}$ \\
\hline \multicolumn{9}{|l|}{8 weeks } \\
\hline$N$ & $92.12 \pm 0.65$ & $84.47 \pm 2.94$ & $184.65 \pm 7.45$ & $183 \pm 7.29$ & $84.47 \pm 2.94$ & $84.47 \pm 2.94$ & $67.94 \pm 0.94$ & $66.32 \pm 0.81$ \\
\hline So & $89.25 \pm 0.75$ & $89.83 \pm 1.76$ & $86.92 \pm 3.86$ & $185 \pm 3.96$ & $89.83 \pm 1.76$ & $89.83 \pm 1.76$ & $63.81 \pm 0.87$ & $64.16 \pm 1.64$ \\
\hline DW & $0 \#, c, a$ & $72.92 \pm 2.62$ & $0 \#, c, a$ & $106.66 \pm 6.08$ & $0 \#, c, a$ & $72.92 \pm 2.61$ & $0 \#, c, a$ & $50.85 \pm 2.28$ \\
\hline VIT E & $0 \#, c, d$ & $81.97 \pm 3.05$ & $0 \#, c, d$ & $150.62 \pm 7.67^{*}$ & $0 \#, c, \alpha$ & $81.97 \pm 3.05$ & $0 \#, c, a$ & $59.7 \pm 2.66^{*}$ \\
\hline AE 60 & $0 \#, c, a$ & $85.59 \pm 3.96^{*}$ & $0 \#, c, \alpha$ & $176.35 \pm 4.03^{* *}, \Delta_{\bullet}$ & $0 \#, c, a$ & $85.59 \pm 3.96^{*}$ & $0 \#, c, \alpha$ & $77.20 \pm 2.62^{* * *}$ \\
\hline ME 60 & $0 \#, c, d$ & $86.54 \pm 2.37^{*}$ & $0 \#, c, d$ & $147.50 \pm 5.90^{* *, \Delta}$ & $0 \#, c, \alpha$ & $86.54 \pm 2.37^{*}$ & $0 \#, c, d$ & $79.75 \pm 1.33^{* * *}$ \\
\hline
\end{tabular}

All values are expressed as mean \pm SEM. Number of rat per group $=5$

$N$ normal, SO sham operated, DW distilled water, VIT $E$ vitamin $E, A E$ aqueous extract, ME methanolic extract

$\#: p<0.001$ compared to normal; $c$ : $p<0.001$ compared to sham operated; ${ }^{*} p<0.05 ;{ }^{* *} p<0.01 ;{ }^{* * *} p<0.001$ compared to DW; $\mathrm{a}: p<0.001$ compared to left testis

(same group); $\Delta p<0.001$ compared to week 2 (same group); $\cdot p<0.001$ compared to week 4 (same group) 
Table 2 Effects of different treatments on sperm abnormalities

\begin{tabular}{|c|c|c|c|c|c|c|c|c|}
\hline \multicolumn{9}{|c|}{ Sperm morphological abnormalities } \\
\hline \multirow[t]{2}{*}{ Groups } & \multicolumn{2}{|c|}{ Abnormal head (\%) } & \multicolumn{2}{|c|}{ Abnormal tail (\%) } & \multicolumn{2}{|c|}{ Tailless head (\%) } & \multicolumn{2}{|c|}{ Cytoplasmic droplet (\%) } \\
\hline & Right testis & Left testis & Right testis & Left testis & Right testis & Left testis & Right testis & Left testis \\
\hline \multicolumn{9}{|l|}{2 weeks } \\
\hline $\mathbf{N}$ & $4.11 \pm 0.59$ & $3.86 \pm 0.40$ & $3.73 \pm 0.36$ & $3.52 \pm 0.26$ & $3.88 \pm 0.58$ & $3.81 \pm 0.86$ & $4.3 \pm 0.90$ & $4.39 \pm 1.19$ \\
\hline so & $3.84 \pm 0.46$ & $3.48 \pm 0.36$ & $4.07 \pm 0.50$ & $4.87 \pm 0.40]$ & $3.28 \pm 0.69$ & $3.30 \pm 1.62$ & $2.72 \pm 0.91$ & $2.43 \pm 1.08$ \\
\hline DW & $0^{\#, c, a}$ & $21.41 \pm 1.79^{\#, c}$ & $0^{\#, c, x}$ & $21.17 \pm 3.30^{\#, c}$ & $0^{\#, c, a}$ & $7.56 \pm 1.43^{\#, c}$ & $0^{\#, c, ~ a ~}$ & $9.44 \pm 0.61^{\#, c}$ \\
\hline VIT E & $0^{\#, c, a}$ & $4.71 \pm 0.62^{* * * *}$ & $0^{\#, c, \alpha}$ & $5.90 \pm 0.62^{* * *}$ & $0^{\#, c, a}$ & $5.29 \pm 1.27$ & $0^{\#, c, a}$ & $5.29 \pm 1.27$ \\
\hline AE 12 & $0^{\#, c, a}$ & $10.01 \pm 2.59^{* * *}$ & $0^{\#, c, x}$ & $12.32 \pm 1.77^{*}$ & $0^{\#, c, a}$ & $7.30 \pm 1.58$ & $0^{\#, c, a}$ & $6.33 \pm 1.33$ \\
\hline AE 60 & $0^{\#, c, a}$ & $7.34 \pm 0.36^{* * *}$ & $0^{\#, c, x}$ & $8.49 \pm 1.89^{* * *}$ & $0^{\#, c, a}$ & $5.98 \pm 1.63$ & $0^{\#, c, a}$ & $6.31 \pm 0.89$ \\
\hline ME 12 & $0^{\#, c, a}$ & $11.12 \pm 0.59^{* * *}$ & $0^{\#, c, ~ a ~}$ & $15.59 \pm 1.54^{*}$ & $0^{\#, c, a}$ & $6.41 \pm 1.73$ & $0^{\#, c, a}$ & $6.19 \pm 0.5$ \\
\hline ME 60 & $0^{\#, c, a}$ & $6.93 \pm 1.13^{* * *}$ & $0^{\#, c, a}$ & $11.91 \pm 0.57^{* *}$ & $0^{\#, c, a}$ & $4.17 \pm 0.40$ & $0^{\#, c, a}$ & $3.74 \pm 0.75^{* *}$ \\
\hline \multicolumn{9}{|l|}{4 weeks } \\
\hline $\mathrm{N}$ & $3.22 \pm 0.42$ & $3.96 \pm 0.45$ & $3.97 \pm 0.46$ & $3.42 \pm 0.47$ & $3.25 \pm 0.94$ & $3.70 \pm 0.61$ & $4.18 \pm 1.04$ & $4.74 \pm 0.99$ \\
\hline so & $3.28 \pm 0.27$ & $3.98 \pm 0.51$ & $4.28 \pm 0.31$ & $5.02 \pm 0.53$ & $4.91 \pm 0.92$ & $3.58 \pm 0.83$ & $3.56 \pm 0.77$ & $3.13 \pm 0.76$ \\
\hline DW & $0^{\#, c, \infty}$ & $23.51 \pm 1.29^{\#, c}$ & $0^{\#, c, ~ a ~}$ & $22.15 \pm 2.30^{\#, c}$ & $0^{\#, c, ~ a ~}$ & $8.34 \pm 0.94^{\#, c}$ & $0^{\#, c, n}$ & $10.14 \pm 1.50^{\#, c}$ \\
\hline VIT E & $0^{\#, c, a}$ & $6.80 \pm 0.52^{* * *}$ & $0^{\#, c, ~ a ~}$ & $4.30 \pm 0.42^{* * *}$ & $0^{\#, c, a}$ & $6.19 \pm 1.40$ & $0^{\#, c, ~ a ~}$ & $6.22 \pm 1.37$ \\
\hline AE 12 & $0^{\#, c, x}$ & $12.04 \pm 1.34^{* * *}$ & $0^{\#, c, \alpha}$ & $11.52 \pm 1.86^{*}$ & $0^{\#, c, a}$ & $8.91 \pm 1.24$ & $0^{\#, c, a}$ & $7.66 \pm 1.91$ \\
\hline AE 60 & $0^{\#, c, a}$ & $5.25 \pm 0.47^{* * *}$ & $0^{\#, c, ~ a ~}$ & $7.57 \pm 1.32^{* * *}$ & $0^{\#, c, \infty}$ & $4.80 \pm 1.52$ & $0^{\#, c, a}$ & $5.10 \pm 0.54$ \\
\hline ME 12 & $0^{\#, c, a}$ & $12.42 \pm 0.67^{* * *}$ & $0^{\#, c, \infty}$ & $14.09 \pm 1.64^{*}$ & $0^{\#, c, a}$ & $7.48 \pm 0.97$ & $0^{\#, c, a}$ & $8.21 \pm 0.75$ \\
\hline ME 60 & $0^{\#, c, a}$ & $5.99 \pm 0.97^{* * *}$ & $0^{\#, c, a}$ & $10.82 \pm 0.68^{* *}$ & $0^{\#, c, ~ a ~}$ & $4.65 \pm 0.49$ & $0^{\#, c, ~ a ~}$ & $3.14 \pm 0.86^{* *}$ \\
\hline \multicolumn{9}{|l|}{8 weeks } \\
\hline $\mathbf{N}$ & $4.25 \pm 0.45$ & $4.26 \pm 0.56$ & $3.92 \pm 0.32$ & $3.17 \pm 0.16$ & $3.70 \pm 0.46$ & $3.95 \pm 0.26$ & $5.09 \pm 0.75$ & $5.49 \pm 1.09$ \\
\hline so & $3.52 \pm 0.41$ & $3.47 \pm 0.30$ & $3.96 \pm 0.39$ & $3.87 \pm 0.50$ & $6.41 \pm 0.88$ & $5.07 \pm 0.94$ & $4.73 \pm 0.39$ & $3.85 \pm 0.45$ \\
\hline DW & $0^{\#, c, a}$ & $22.47 \pm 1.39^{\#, c}$ & $0^{\#, c, a}$ & $21.17 \pm 3.35^{\#, c}$ & $0^{\#, c, a}$ & $8.56 \pm 1.43^{\#, c}$ & $0^{\#, c, ~ a ~}$ & $9.56 \pm 0.66^{\#, c}$ \\
\hline VIT E & $0^{\#, c, a}$ & $4.70 \pm 0.61^{* * *}$ & $0^{\#, c, ~ a ~}$ & $5.90 \pm 0.98^{* * *}$ & $0^{\#, c, a}$ & $5.29 \pm 1.27$ & $0^{\#, c, ~ a ~}$ & $5.29 \pm 1.27$ \\
\hline AE 60 & $0^{\#, c, a}$ & $7.6 \pm 2.15^{* * *}$ & $0^{\#, c, \infty}$ & $9.40 \pm 2.20^{* *}$ & $0^{\#, c, \infty}$ & $7.60 \pm 1.17$ & $0^{\#, c, ~ a ~}$ & $4.40 \pm 0.75^{* *}$ \\
\hline ME 60 & $0^{\#, c, a}$ & $5.55 \pm 1.44^{* * *}$ & $0^{\#, c, ~ a ~}$ & $9.63 \pm 1.55^{* *}$ & $0^{\#, c, a}$ & $7.18 \pm 0.55$ & $0^{\#, c, a}$ & $1.18 \pm 0.59^{* * *}$ \\
\hline
\end{tabular}

All values are expressed as mean \pm SEM. Number of rats per group $=5$

$N$ normal, SO sham operated, DW distilled water, VIT $E$ vitamin $E, A E$ aqueous extract, $M E$ methanolic extract

$\#: p<0.001$ compared to normal; $c$ : $p<0.001$ compared to sham operated; ${ }^{*} p<0.05 ;{ }^{* *} p<0.01 ;{ }^{* * *} p<0.001$ compared to DW; $\mathrm{a}: p<0.001$ compared to left testis (same group)

treatment periods, the highest dose of plant extracts $(60$ $\mathrm{mg} / \mathrm{kg}$ ) was the most effective in the cryptorchid testis (Fig. 3).

\section{Effect of different treatments on oxidative stress markers}

The occurrence of cryptorchism was associated with oxidative stress characterized in the right testis by a significant decrease $(p<0.05)$ in catalase and SOD activities and a high lipid peroxidation (increase in MDA).

Vitamin $\mathrm{E}$ and $R$. apetalus significantly $(p<0.05)$ decreased MDA level in the right testis after 2 weeks (aqueous extract at $12 \mathrm{mg} / \mathrm{kg}$ ), 4 weeks (aqueous and methanolic extracts at $12 \mathrm{mg} / \mathrm{kg}$ and $60 \mathrm{mg} / \mathrm{kg}$ ) and 8 weeks (aqueous and methanolic extracts at $60 \mathrm{mg} / \mathrm{kg}$ ) of treatment, compared to the untreated cryptorchid rats (Fig. 4a).
SOD activity in the right testis was significantly $(p<0.05)$ elevated in rats given $R$. apetalus for 2 weeks (aqueous extract at $60 \mathrm{mg} / \mathrm{kg}$ ), 4 weeks (aqueous extract at $60 \mathrm{mg} / \mathrm{kg}$ and methanolic extract at 12 $\mathrm{mg} / \mathrm{kg}$ and $60 \mathrm{mg} / \mathrm{kg}$ ) and 8 weeks (aqueous and methanolic extracts at $60 \mathrm{mg} / \mathrm{kg}$ ), compared to the untreated cryptorchid group. In the left testis, SOD activity was also increased $(p<0.05-0.01)$ in rats treated with vitamin $\mathrm{E}$ (2 weeks) and methanolic extract of $R$. apetalus $(60 \mathrm{mg} / \mathrm{kg} ; 2$ and 8 weeks) compared to DW group. In both testes, the effects of vitamin $\mathrm{E}$ and $R$. Apetalus were more pronounced after 8 weeks of treatment (Fig. 4b).

The decrease observed in catalase activity in the cryptorchid testis was reversed in a dose-dependent manner after vitamin $\mathrm{E}$ and $R$. apetalus treatments (Fig. 4c). 


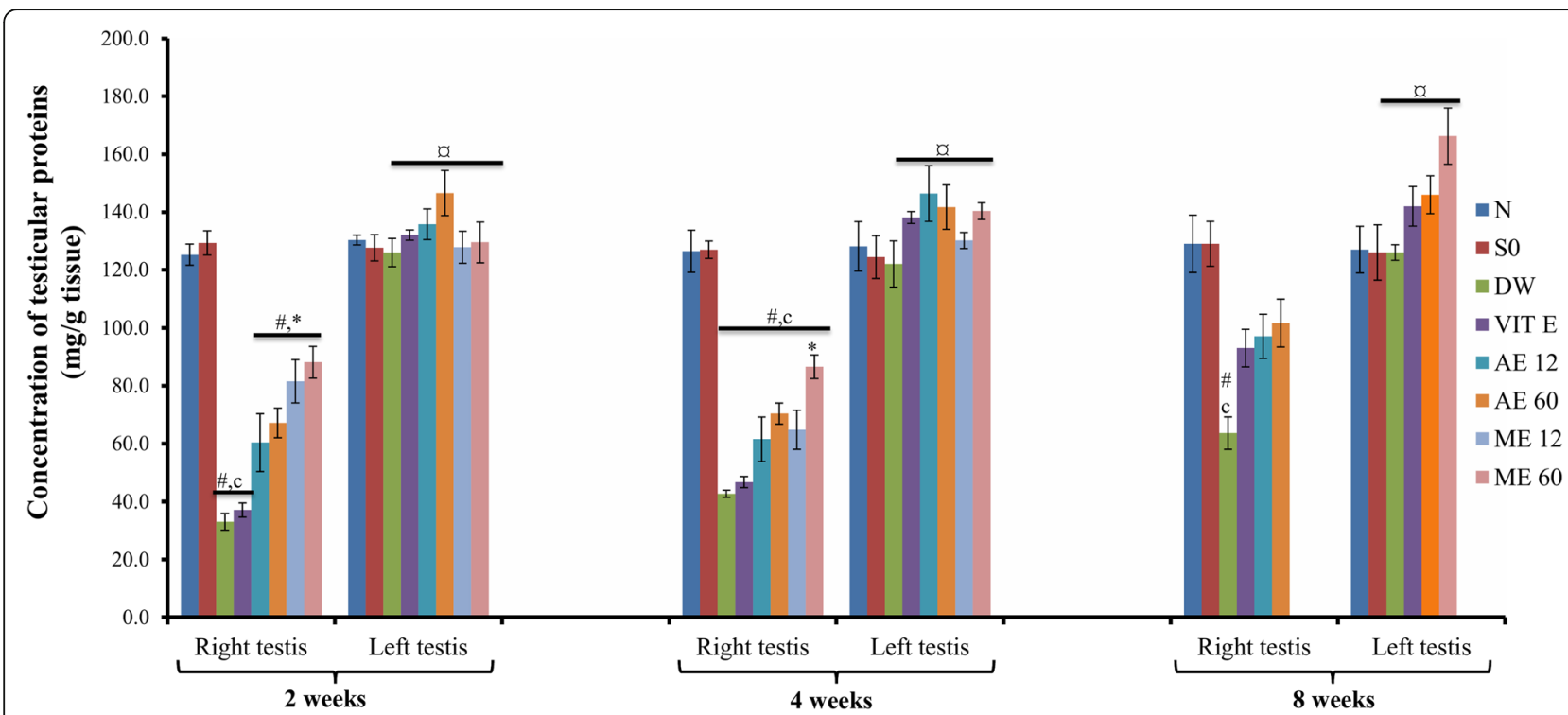

Fig. 3 Effects of different treatments on testicular protein levels. Values are mean \pm SEM. Number of rats per group $=5$. c: $p<0.001$ compared to sham operated; $: p<0.001$ compared to normal; ${ }^{p} p<0.001$ compared to $D W ; \alpha: p<0.001$ compared to right testis (same group);Abbreviations: N: normal; SO: sham operated; DW: distilled water; Vit E: vitamin E; AE12 / AE60: aqueous extract administered at 12 mg/kg or 60 mg/kg; ME12 / ME60: methanolic extract administered at $12 \mathrm{mg} / \mathrm{kg}$ or $60 \mathrm{mg} / \mathrm{kg}$

\section{Effect of different treatments on sex hormones}

Plasmatic testosterone, LH and FSH levels were significantly $(p<0.001)$ decreased after cryptorchidism set up. Vitamin $\mathrm{E}$ and $R$. apetalus extracts elevated the plasmatic testosterone level in a time-dependent manner. In the cryptorchid rats, the highest value of plasmatic testosterone was observed in animals administered for 8 weeks with the aqueous extract of $R$. apetalus $(60 \mathrm{mg} /$ kg) (Fig. 5a). Compared to the DW group, we noticed that the plasmatic LH level was significantly $(p<0.01-$ 0.001 ) increased in rats treated for 2 and 8 weeks with vitamin $\mathrm{E}$ and $R$. apetalus (both extracts at all doses) (Fig. 5b). R. apetalus also increased $(p<0.05-0.001)$ the plasmatic FSH level (in a dose-dependent manner) after 2,4 and 8 weeks of treatment. In rats given vitamin $\mathrm{E}$, the plasmatic FSH level increased gradually $(p<0.01-$ 0.001) from week 2 to week 8 (Fig. 5c).

\section{Effect of different treatments on morphometric characteristics of testis}

Cryptorchidism significantly $(p<0.001)$ decreased the diameter of the seminiferous tubes and seminiferous epithelium thickness, and increased peri-vascular fibrosis in the right testis, but did not affect the left testis. Vitamin E significantly $(p<0.05-0.001)$ increased the diameter of the seminiferous tubes (both testis: weeks 4 and 8 ) and seminiferous epithelium thickness (left testis: weeks 2 and 8), and decreased the peri-vascular fibrosis (right testis: weeks 2, 4 and 8) compared to DW group. Similarly, $R$. apetalus (all doses) increased $(p<0.05-0.001)$ the diameter of the seminiferous tubes and seminiferous epithelium thickness, but decreased $(p<0.05-0.001)$ the peri-vascular fibrosis in the right testis after 2,4 and 8 weeks of treatment (Table 3).

\section{Effect of different treatments on fertility potential}

The fertility potential of cryptorchid rats was evaluated using females with proven fertility. A decrease in gestation index $(62.5 \%)$ and fertility index $(50.00 \%)$ was observed when compared to normal and sham operated animals. After vitamin $\mathrm{E}$ and $R$. apetalus treatments, an improvement of gestation index and fertility index was recorded. The methanolic extract of $R$. apetalus was the most active extract (Table 4).

\section{Discussion}

Cryptorchidism is an endocrinopathy considered as an important cause of male infertility [42]. The current study evaluated the effects of aqueous and methanolic extracts of $R$. apetalus on various reproductive (organ weights, spermatozoa parameters, testicular proteins, sex hormones, fertility potential and morphometric characteristics of testis) and metabolic (oxidative stress markers) parameters in unilateral induced cryptorchid rats. Results from this study showed that $R$. apetalus improved the fertility potential of cryptorchid rats by increasing the relative weight of testes and epididymis and, alleviating spermatozoa characteristics, testicular proteins and sex hormones in one hand, and by reducing the oxidative stress in the testis through a significant decrease in MDA and a high SOD and catalase activities in the other hand. 


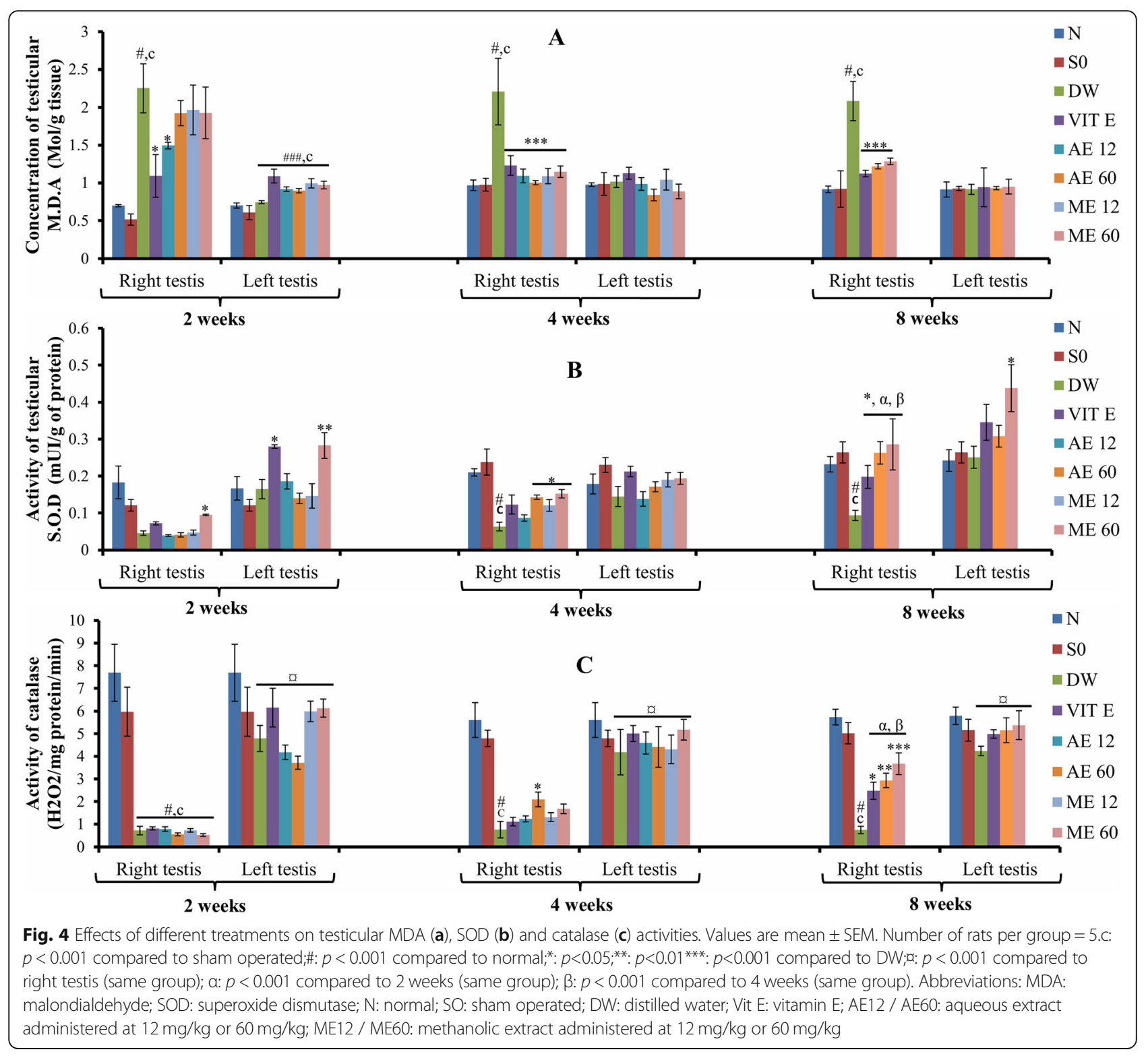

CPT can experimentally be induced by several techniques including surgery, hormone application or transgenic methods [32, 33]. After induction, the testicular weight decreases gradually due to hormonal depletion, with atrophy and few germinal cells, which negatively affect steroidogenesis and spermatogenesis $[33,43]$. In this study, the surgical CPT model was chosen. In rats; this model induces a CPT similar to human CPT. We noticed that all rats developed unilateral cryptorchidism after induction, as also reported by Muhammetnur et al. [18].

Testicular and epididymal weights are good indicators of cryptorchidism. As reported by Muhammetnur et al. [18], the relative weights of testes and epididymis were significantly lowered in cryptorchid animals, compared with control. Indeed, cryptorchidism is associated with lipid peroxidation and oxidative stress, characterized by an excessive production of reactive oxygen species (ROS), which induce apoptosis in the testes and cause degeneration of the germinal epithelium of seminiferous tubules, leading to low testicular weight [44]. The decrease in epididymal weight may result from a quantitatively reduced spermatogenesis (as indicated by azoospermia). In each cryptorchid rat given vitamin $\mathrm{E}$ or plant extracts, the left testicular and epididymal weights were significantly increased compared to the right side. This result was expected because of the cryptorchidism condition of the right epididymis. Similar findings were reported by Muhammetnur et al. [18].

Cryptorchidism seriously damaged steroidogenesis and spermatogenesis. In the right epididymis, no spermatozoa was found whereas spermatozoa morphology 


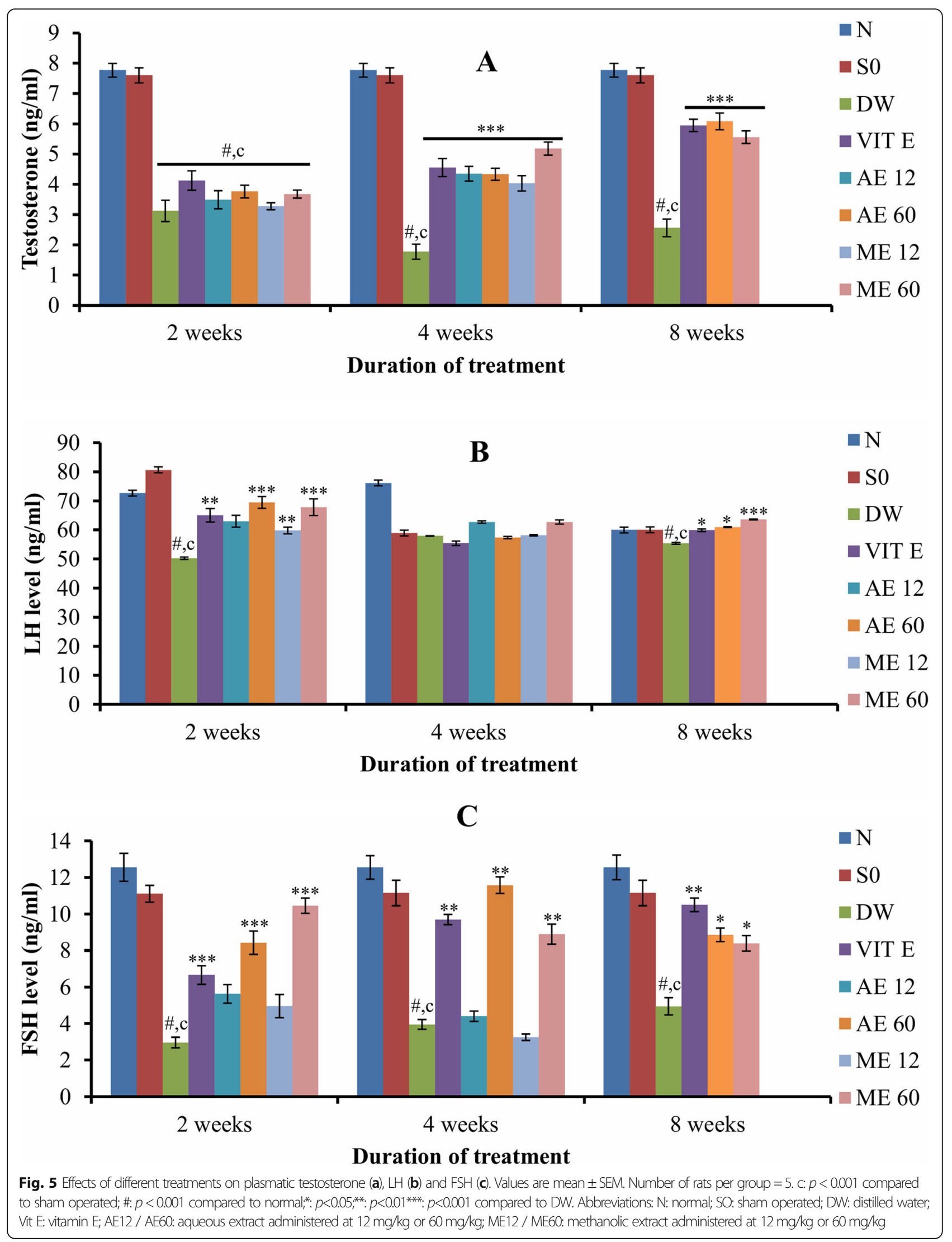


Table 3 Effect of different treatments on the diameter of the seminiferous tubes, seminiferous epithelium thickness and perivascular fibrosis

\begin{tabular}{|c|c|c|c|c|c|c|}
\hline \multirow[t]{2}{*}{ Groups } & \multicolumn{2}{|c|}{$\begin{array}{l}\text { Diameter of the seminiferous } \\
\text { tubes }(\mu \mathrm{m})\end{array}$} & \multirow{2}{*}{$\begin{array}{l}\text { Germ cell thickness }(\mu \mathrm{m}) \\
\text { Right testis }\end{array}$} & \multicolumn{3}{|c|}{ Peri-vascular fibrosis ( $\mu \mathrm{m})$} \\
\hline & Right testis & Left testis & & Left testis & Right testis & Left testis \\
\hline \multicolumn{7}{|l|}{2 weeks } \\
\hline $\mathbf{N}$ & $653.63 \pm 12.30$ & $656.73 \pm 12.73$ & $229.87 \pm 7.07$ & $234.35 \pm 5.24$ & $16.63 \pm 1.82$ & $16.12 \pm 1.81$ \\
\hline so & $652.21 \pm 12.30$ & $662.39 \pm 10.23$ & $230.86 \pm 8.72$ & $238.20 \pm 8.78$ & $16.41 \pm 1.87$ & $16.52 \pm 1.72$ \\
\hline DW & $436.64 \pm 12.89^{\#, c, \alpha}$ & $663.31 \pm 10.80$ & $0^{\#, c, \alpha}$ & $234.26 \pm 6.46$ & $48.30 \pm 2.76^{\#, c, a}$ & $16.87 \pm 2.31$ \\
\hline VIT E & $461.91 \pm 12.30$ & $683.26 \pm 11.63$ & $0^{\#, c, \alpha}$ & $277.43 \pm 10.08^{* *}$ & $33.91 \pm 1.41^{* * *}$ & $14.52 \pm 1.03$ \\
\hline AE 12 & $441.76 \pm 9.76$ & $681.67 \pm 8.80$ & $0^{\#, c, \alpha}$ & $331.69 \pm 8.88^{* * *}$ & $28.06 \pm 2.87^{* * *}$ & $13.33 \pm 1.00$ \\
\hline AE 60 & $481.91 \pm 8.05^{* *}$ & $696.91 \pm 8.85$ & $0^{\#, c, a}$ & $331.21 \pm 11.59^{* * * *}$ & $27.76 \pm 2.03^{* * *}$ & $12.46 \pm 0.91$ \\
\hline ME 12 & $480.46 \pm 9.18^{* * *}$ & $667.91 \pm 10.37$ & $0^{\#, c, a}$ & $358.79 \pm 12.71^{* * *}$ & $25.01 \pm 0.95^{* * *}$ & $14.60 \pm 1.40$ \\
\hline ME 60 & $498.59 \pm 9.49^{* * *}$ & $669.76 \pm 12.89$ & $0^{\#, c, a}$ & $373.02 \pm 12.91^{* * *}$ & $24.94 \pm 1.17^{* * *}$ & $11.46 \pm 1.19$ \\
\hline \multicolumn{7}{|l|}{4 weeks } \\
\hline $\mathbf{N}$ & $659.93 \pm 9.32$ & $658.1 \pm 7.52$ & $228.83 \pm 8.50$ & $236.49 \pm 9.39$ & $15.65 \pm 2.650$ & $16.58 \pm 2.68$ \\
\hline so & $655.41 \pm 12.09$ & $661.36 \pm 11.68$ & $229.41 \pm 9.13$ & $240.87 \pm 10.48$ & $16.64 \pm 1.31$ & $16.30 \pm 1.01$ \\
\hline DW & $387.51 \pm 7.37^{\#, c, a}$ & $658.29 \pm 9.76$ & $0^{\#, c, a}$ & $227.03 \pm 7.29$ & $40.10 \pm 3.26^{\#, c, \alpha}$ & $16.02 \pm 1.02$ \\
\hline VIT E & $476.63 \pm 11.65^{* * *}$ & $674.2 \pm 12.97^{*}$ & $0^{\#, c, a}$ & $273.39 \pm 6.41$ & $34.98 \pm 1.09^{* * *}$ & $16.40 \pm 0.63$ \\
\hline AE 12 & $444.09 \pm 9.03^{* * *}$ & $690.06 \pm 6.86$ & $0^{\#, c, a}$ & $335.89 \pm 11.20^{*}$ & $27.58 \pm 0.95^{* * *}$ & $12.03 \pm 2.23$ \\
\hline AE 60 & $464.37 \pm 12.63^{* * * *}$ & $721.57 \pm 11.76$ & $0^{\#, c, \infty}$ & $382.97 \pm 12.14^{*}$ & $26.74 \pm 1.06^{* * *}$ & $12.01 \pm 0.95$ \\
\hline ME 12 & $446.34 \pm 12.46^{* * *}$ & $668.67 \pm 12.637$ & $0^{\#, c, \infty}$ & $380.61 \pm 9.22$ & $\left\{24.27 \pm 2.16^{* * *}\right.$ & $16.61 \pm 0.93$ \\
\hline ME 60 & $481.49 \pm 10.19^{* * *}$ & $707.69 \pm 11.54$ & $0^{\#, c, a}$ & $383.66 \pm 10.85^{*}$ & $20.16 \pm 1.68^{* * *}$ & $13.34 \pm 1.15$ \\
\hline \multicolumn{7}{|l|}{8 weeks } \\
\hline $\mathbf{N}$ & $662.31 \pm 9.46$ & $659.86 \pm 7.65$ & $241.26 \pm 6.65$ & $244.38 \pm 7.87$ & $17.20 \pm 1.73$ & $17.17 \pm 1.59$ \\
\hline so & $630.13 \pm 4.30$ & $661.63 \pm 7.31$ & $236.36 \pm 4.50$ & $237.20 \pm 4.66$ & $16.27 \pm 1.23$ & $16.21 \pm 1.35$ \\
\hline DW & $363.46 \pm 9.73^{\#, c, a}$ & $663.89 \pm 10.90$ & $0^{\#, c, \infty}$ & $234.83 \pm 7.48$ & $45.29 \pm 3.84^{\#, c, ~ a ~}$ & $16.33 \pm 1.63$ \\
\hline VIT E & $470.23 \pm 10.45^{* * *}$ & $667.16 \pm 8.36$ & $0^{\#, c, a}$ & $279.73 \pm 7.37^{* * *}$ & $34.53 \pm 1.54^{* * *}$ & $16.82 \pm 1.38$ \\
\hline AE 60 & $491.01 \pm 5.56^{* * *}$ & $683.04 \pm 6.33$ & $0^{\#, c, \infty}$ & $411.59 \pm 3.81^{* * *}$ & $23.90 \pm 1.76^{* * *}$ & $12.89 \pm 0.97$ \\
\hline ME 60 & $495.87 \pm 8.04^{* * *}$ & $740.66 \pm 9.71$ & $0^{\#, c, \infty}$ & $428.69 \pm 7.48^{* * *}$ & $29.60 \pm 1.30^{* * *}$ & $13.94 \pm 1.16$ \\
\hline
\end{tabular}

All values are expressed as mean \pm SEM. Number of rats per group $=5$

Abbreviations: $N$ normal, $S O$ sham operated, $D W$ distilled water, VIT E vitamin $E, A E$ aqueous extract, $M E$ methanolic extract

$\#: p<0.001$ compared to normal; $c: p<0.001$ compared to sham operated; ${ }^{*} p<0.05 ;{ }^{* *} p<0.01 ;{ }^{* * *} p<0.001$ compared to DW; $x: p<0.001$ compared to left testis (same group); $\alpha_{:} p<0.001$ compared to left testis (same group)

Table 4 Effects of different treatments on fertilization potential

\begin{tabular}{|c|c|c|c|c|c|c|}
\hline Groups & $\begin{array}{l}\text { Number of females } \\
\text { mated }\end{array}$ & $\begin{array}{l}\text { Number of females with a } \\
\text { positive vaginal smear }\end{array}$ & $\begin{array}{l}\text { Number of pregnant } \\
\text { females }\end{array}$ & $\begin{array}{l}\text { Gestation index } \\
(\%)\end{array}$ & $\begin{array}{l}\text { Fertility index } \\
(\%)\end{array}$ & $\begin{array}{l}\text { Average litter } \\
\text { size }\end{array}$ \\
\hline $\mathbf{N}$ & 10 & 9 & 9 & 90.00 & 100.00 & $6.67 \pm 0.34$ \\
\hline so & 10 & 9 & 8 & 88.00 & 80.00 & $6.44 \pm 0.37$ \\
\hline DW & 10 & 8 & 5 & 62.5 & 50.00 & $2.90 \pm 0.35$ \\
\hline VIT E & 10 & 9 & 8 & 88.00 & 80.00 & $4.9 \pm 0.043$ \\
\hline AE 60 & 10 & 10 & 9 & 90.00 & 90.00 & $6.50 \pm 0.5$ \\
\hline ME 60 & 10 & 9 & 10 & 100.00 & 100.00 & $6.80 \pm 0.66$ \\
\hline
\end{tabular}

Abbreviations: $N$ normal, $S O$ sham operated, $D W$ distilled water, Vit $E$ vitamin $E, A E$ aqueous extract, $M E$ methanolic extract 
abnormalities (abnormal head, abnormal tail, tailless head and cytoplasmic droplet) were elevated in the contralateral epididymis, compared with normal and sham operated [17, 44]. These abnormal spermatozoa characteristics could be due to the adverse effects of the thermal stress and oxidative stress, which negatively affect spermatogenesis and steroidogenesis. Indeed, under cryptorchidism condition, spermatozoa which are released in the germinal epithelium carry more residual cytoplasm and are then considered as abnormal (defective) [45]. However, $R$. apetalus improved spermatozoa characteristics with a remarkable effect (at all treatment periods) observed in rats administered with the methanolic extract $(60 \mathrm{mg} / \mathrm{kg})$. The effectiveness of methanolic extract in improving the spermatozoa characteristics could be correlated with its ability to easily extract antioxidant compounds such as saponins, alkaloids, flavonoids, tannins, triterpenoids and vitamins $E$ and $C$ [23] and, improve sex hormone levels. Similar results were reported in cryptorchid rats administered with Moringa oleifera [17].

Oxidative stress is considered as an important cause of spermatozoa abnormalities in cryptorchid individuals [46]. It has been shown that high scrotal temperature increases the production of heat shock proteins and free radicals, which negatively affect spermatogenesis, by damaging the purine and pyrimidine bases, leading to abnormal spermatozoa production [18]. Low testicular protein activities as well as an increase in malondialdehyde (MDA) clearly indicate lipid peroxidation. In the present work, cryptorchidism was characterized by a high MDA concentration, low antioxidant enzyme (SOD and catalase) activities and a decrease in testicular protein levels. High testicular temperature promotes ROS overproduction and peroxidation of the spermatozoa membrane, leading to the death of germ cells [47, 48]. Wdowiak et al. showed that a low antioxidant activity is correlated with severe DNA damages in seminal plasma of infertile men [49]. We also noticed that the detrimental effect of oxidative stress on the testicular function was associated with a significant decrease in sex hormones (testosterone, LH and FSH) with an abnormal spermatozoa production. Moreover, the decrease in testicular protein levels could be due to an overproduction of ROS caused by oxidative stress, as reported by Muhammetnur et al. [18]. However, $R$. apetalus decreased lipid peroxidation, but increased SOD and catalase activities, which further confirms its antioxidant property previously reported $[27,28]$. These results corroborate those of Raghavendra et al. who demonstrated the in vitro and in vivo antioxidant potentials of $R$. apetalus in diabetic rats [23, 28]. In parallel, Moringa oleifera possesses a powerful antioxidant potential in cryptorchid rats by improving the antioxidant enzymes $[17,18]$. The antioxidant potential of $R$. apetalus could be justified by the presence of flavonoids, alkaloids and phenols. These phytocomponents are able to stimulate the production of antioxidant enzymes and directly scavenge the ROS [50].

Under cryptorchidism condition, oxidative stress impairs Leydig cell function and causes low testosterone production, leading to abnormal spermatogenesis and infertility [51]. Low LH and FSH also impairs steroidogenesis and spermatogenesis, respectively [52]. The decline in testosterone, LH and FSH levels observed in cryptorchid rats was correlated with abnormal spermatozoa characteristics and therefore indicated an alteration of steroidogenesis and spermatogenesis. Normalization of testosterone level and spermatozoa characteristics in cryptorchid rats given $R$. apetalus could therefore be due to the capacity of the extracts to increase LH and FSH levels. This improvement in sex hormones by $R$. apetalus could again be due to the presence of various phytocomponents such as alkaloids and saponins. These compounds are capable to boost testosterone production $[53,54]$.

As reported by Muhammetnur et al. [18], we found in the current study that cryptorchidism significantly decreased the diameter of the seminiferous tubes, germ cell thickness and increased peri-vascular fibrosis in the right testis, but did not affect the left testis. These structural damages were positively correlated with oxidative stress, low sex hormone production and high morphological spermatozoa abnormalities. These parameters were improved by $R$. apetalus. Since $R$. apetalus improved structural, reproductive and metabolic parameters in cryptorchid rats; it was of great importance to investigate its effect on fertility. We observed that cryptorchidism decreased the gestation index (62.5\%) and fertility index (50\%), which could justify the spermatic, hormonal and structural alterations observed in cryptorchid rats. These drops in fertility parameters were reversed by $R$. apetalus extracts. Because cryptorchidism is a congenital anomaly, examination of the effects of $R$. apetalus in juvenile rats is highly needed.

\section{Conclusion}

Taking together, these findings demonstrated that $R$. apetalus boosts fertility by improving spermatozoa characteristics, sex hormone levels, testicular proteins and antioxidant enzymes in cryptorchid rats. The aqueous and methanolic extracts of $R$. apetalus could be considered as promising alternative agents for the management of cryptorchidism related hypofertility. However, a test to verify its safety is required. 


\section{Abbreviations}

CAT: Catalase; CPT: Cryptorchidism; DW: Distilled water; FSH: Follicle stimulating hormone; LH: Luteinizing hormone; MDA: Malondialdehyde; SOD: Superoxide dismutase

\section{Acknowledgements}

Authors would like to thank Mr. Balagizi Karhagomba Innocent (Ethnobotanist), Université Evangélique en Afrique and Pain Pour le Monde (Brot) for plant collection and material support respectively.

\section{Authors' contributions}

DAM participated in the study conception, implementation, data analysis and, drafted the manuscript; ACTM, GRBF, PBDD, YPT and BL participated in the study conception, implementation and manuscript review; PW supervised this study from the conception to manuscript review and validation. All co-authors read and approved the final manuscript.

\section{Funding}

This study did not benefit from financial support from any third party or organization.

\section{Availability of data and materials}

Data are available upon request.

\section{Ethics approval and consent to participate}

The project was presented and validated by the scientific committee of the Department of Animal Biology, University of Dschang, which follows the internationally accepted standard ethical guidelines for laboratory animal use and care as described in the European Economic Community guidelines; EEC. 2010 Council Directive 2010/63/EU of 22 November 2010 [30].

\section{Consent for publication}

Not applicable.

\section{Competing interests}

The authors declare that they have no competing interests.

\section{Author details}

${ }^{1}$ Research Unit of Animal Physiology and Phytopharmacology (URPAP), Faculty of Science, University of Dschang, Dschang, Box 67, Dschang, Cameroon. ${ }^{2}$ School of Medicine and Community Health, Université Evangelique en Afrique, Bukavu, Democratic Republic of Congo.

Received: 1 April 2020 Accepted: 22 June 2020

Published online: 09 July 2020

\section{References}

1. Thorup J, Kvist K, Clasen-Linde PBL, Cortes D. The relation between adult dark spermatogonia and other parameters of fertility potential in cryptorchid testes. J Urol. 2013;190(4 Suppl):1566-71.

2. Rodprasert W, Virtanen HE, Mäkelä JA, Toppari J. Hypogonadism and cryptorchidism. Front Endocrinol. 2020;15(10):906. https://doi.org/10.3389/ fendo.2019.00906.

3. Robin G, Boitrelle F, Marcelli F, Collin P, Leroy-Martin B, Mitchell V, et al. Cryptorchidie: de la physiopathologie à l'infertilité. [cryptorchidism: from pathophysiology to infertility]. Gynecol Obset Ferti. 2010;38:588-99.

4. Wugang H, Hu J, Li Y, Zhao J, Li Z, Liu X, Yao L, Zhang Y. Altered expression of NDRG2 in testis of experimental rat model of cryptorchidism. J Urol. 2010;75(4):985-91.

5. Leslie DT, Sutchin RP, Anthony AC. A history of cryptorchidism: lessons from the eighteenth century. J Pediatr Urol. 2007;3:426-32.

6. Castillo-Ortiz J, Muniz-Colon L, Escudero K, Perez-Brayfield M. Laparoscopy in the surgical management of the non-palpable testis. Front Pediatr. 2014 2(28):1-4.

7. Alumeti MD, Cikwanine B, Tetsatsi MA, Kavira IP, Luhiriri NL, Nanga BD, et al Epidemiology, diagnosis and therapeutic approaches of cryptorchidism at the Panzi General Hospital, DR Congo: a 5-year retrospective study. Ethiop J Health Sci. 2020;30(1):107-14.

8. Cobellis G, Noviello C, Nino F, Romano M, Mariscoli F, Martino A, et al. Spermatogenesis and cryptorchidism. Front Endocrinol. 2014;63:5.
9. Stewart RJ, Boyd S, Brown S, Toner PG. The blood-testis barrier in experimental unilateral cryptorchidism. J Pathol. 1990;160:51-5.

10. Fawzy F, Hussein A, Eid MM, Kashash AME, Salem HK. Cryptorchidism and fertility. Clin Med Insights Reprod Health. 2005;9:35-43.

11. Niedzielski JK, Oszukowska E, Słowikowska-Hilczer J. Undescended testiscurrent trends and guidelines: a review of the literature. Arch Med Sci. 2016; 12(3):667-77.

12. Lip SZ, Murchison LE, Cullis PS, Govan L, Carachi R. A meta-analysis of the risk of boys with isolated cryptorchidism developing testicular cancer in later life. Arch Dis Child. 2013;98(1):20-6.

13. Ritzén EM, Bergh A, Bjerkens R, Christiansen P, Corrtes D, Haugen SE, et al. Nordic consensus on treatment of undescended testes. Acta Paediatr. 2007; 96:638-43.

14. Sapin E. Ectopie testiculaire et cryptorchidie de quoi parle-t-on? Indications opératoires. Arch Pédiatr. 2013;21(1):113-7.

15. Ryang SH, Jung JH, Eom M, Song JM, Chung HC, Chae Y, et al. The incidence and histological characteristics of intratubular germ cell neoplasia in post-pubertal cryptorchid testis. Korean J Urol. 2015;56(7):515-8.

16. Afolabi $\mathrm{AO}$, Olotu $\mathrm{OO}$, Alagbonsi IA. Vitamins $\mathrm{E}$ and $\mathrm{C}$ alleviate the germ cell loss and oxidative stress in cryptorchidism when administered separately but not when combined in rats. ISRN Pharmacology. 2012;2012:1-8.

17. Afolabi $\mathrm{AO}$, Aderoju $\mathrm{HA}$, Alagbonsi IA. Effects of methanolic extract of Moringa oleifera leaves on semen and biochemical parameters in cryptorchid rats. Afr J Tradit Complement Altern Med. 2013;10(5):230-5.

18. Muhammetnur T, Nuray B, Khandakar ASMS, Mehmet T, Mehmet $Y$, Hasan $U$, et al. Effects of Moringa oleifera lam extract (MOLE) in the heat shock protein 70 expression and germ cell apoptosis on experimentally induced cryptorchid testes of rats. Gene. 2019;688(10):140-50.

19. Qin D, Tang Y, Wang X, Mao Y, Feng Z. Antagonistic effect of Cuscuta chinensis on a rat model with unilateral cryptorchidism. Med Sci Monit. 2019;7(25):6727-35.

20. Hamill FA, Apio S, Mubiru NK, Mosango M, Bukenya-Ziraba R, Maganyi OW, et al. Traditional herbal drugs of southern Uganda. Part III: isolation and methods for physical characterization of bioactive alkanols from Rubus apetalus. J Ethnopharmacol. 2003;87:15-9.

21. Ganas J, Robbins MM, Nkurunnungi JB, Kaplin BA, McNeilage A. Dietary variability of mountain gorillas in Bwindi impenetrable national park, Uganda. Int J Primatol. 2004;25(5):1043-72.

22. Moges E, Balakrishanan M. Nutritional composition of food plants of geladas (Theropithecus gelada) in Guassa community protected area. JBAH. 2014; 4(23):38-44

23. Raghavendra HL, Shivaleela PU, Reyes DRA, Floriano FJ. Antibiabetic and antioxydant activity of Rubus apetalus Poir. And Rubus steudneri Schweinf. Leaf extract on alloxan induced diabetes mellitus. J Bioanal Biomed. 2019; 11(2):149-54.

24. Balagizi KI, Mirindi AT, Mushagalusa TB, Nabino VB, Koh K, Kim SH. The cultivation of wild food and medicinal plants for improving community livelihood: the case of the Buhozi site, DR Congo. Nutr Res Pract. 2013;7(6): 510-8.

25. Chifundera K. Antivenomous plants used in Zairean pharmacopeia. Afr Stud Monogr. 1987;7:21-35.

26. Seshathri K. Antimicrobial properties of Ethiopian chewing sticks against candida albicans. J Appl Pharm Sci. 2012;2(1):45-50.

27. Tadesse S, Asres K, Veeresham C. Antioxidant activities of three Rubus species growing in Ethiopia. Ethiop Pharm J. 2007;25(2):103-10.

28. Raghavendra HL, Prashithkekuda TR, Chetan DM. Phytochemical analysis and in vitro antioxidant activity of Rubus apetalus Poir (Rosaceae). Pharmacologyonline. 2018;1:187-95.

29. Deeh-Defo PB, Wankeu-Nya M, Ngadjui E, Fozin BGR, Kemka FX, Kamanyi A, et al. The methanolic extract of Guibourtia tessmannii (Caesalpiniaceae) improves sexual parameters in high fat diet-induced obese sexually sluggish rats. Asian Pac J Reprod. 2017;6(5):202-11.

30. EEC. Directive 2010/63/EU of the European Parliament and of the Council of 22 September 2010 on the protection of animals used for scientific purposes. Official Journal of the European Union. 2010;L276:33-79.

31. Toshihiko S, Billig H, Aaron J. Experimentally induced cryptorchidism increases apoptosis in rat testis. Biol Reprod. 1994;51:865-72.

32. Mizuno K, Hayashi Y, Kojima Y, Kurokawa S, Sasaki S, Kohni K. Influence for testicular development and histological peculiarity in the testes of flutamide-induced cryptorchid rat model. Int J Urol. 2007;14(1):67-72. 
33. Liu F, Huang H, Xu ZL, Qian XJ, Qiu WY. Germ cell removal after induction of cryptorchidism in adult rats. Tissue Cell. 2012;44(5):281-7.

34. Russell LD, Ettlin RA, Hikim AP, Clegg ED. The classification and timing of spermatogenesis. In: Russell LD, Ettlin RA, Hikim AP, Clegg ED, editors. Histological and histopathological evaluation of the testis Clearwater. St. Louis: Cache River Press; 1990. p. 41-58.

35. Ratnassoriya WD, Dharmasiri MG. Effects of Terminalia catappa seeds on sexual behaviour and fertility of male rats. Asian J Androl. 2000;2:213-9.

36. Kemka NFX, Deeh DPB, Wankeu-Nya M, Ngadjui E, Kamanyi A, Kamtchouing $P$, Watcho P. Preventive effects of Aframomum melegueta extracts on the reproductive complications of propylthiouracil induced hypothyroidism in male rat. Andrologia. 2019;51:e13306. https://doi.org/10.1111/and.13306.

37. Ngoula F, Watcho P, Bouseko TS, Kenfack A, Tchoumboue J, Kamtchouing P. Effect of propoxur on the reproductive system of male rats. Afr J Reprod Health. 2007:11:125-32.

38. Kiran KS, Li TZ, Bo RC, Keshab KK, Jae HY, Yu SS, et al. Protective effect of Motiliperm in varicocele-induced oxidative injury in rat testis by activating phosphorylated inositol requiring kinase 1a(p-IRE1a) and phosphorylated cJun N-terminal kinase (p-JNK) pathways. Pharm Biol. 2018;56(1):94-103.

39. Dimo T, Tsala D, Djeufiet P, Beng V, Njifutie N. Effect of Alafia multiflora stapf on lipid peroxydation and antioxidant enzyme status in rats. Pharmacologyonline. 2006;2:76-89.

40. Dou L, Zheng Y, Li L, Gui X, Chen Y, Yu M, Guo Y. The effect of cinnamon on polycystic ovary syndrome in a mouse model. Reprod Biol Endocrinol. 2018;16(1):99.

41. Rezvanfar MA, Rezvanfar MA, Shahverdi AR, Ahmadi A, Baeeri M, Mohammadirad A, et al. Protection of cisplatin-induced spermatotoxicity, DNA damage and chromatin abnormality by selenium nano-particles. Toxicol Appl Pharmacol. 2013;266(3):356-65.

42. Hadziselimovic F, Verkauskas G, Vincel B, Stadler MB. Testicular expression of long non-coding RNAs is affected by curative GnRHa treatment of cryptorchidism. Basic Clin Androl. 2019;29:18. https://doi.org/10.1186/ s12610-019-0097-3.

43. Zakaria O, Shono T, Imajima T, Suita S. Fertility and histological studies of the contralateral testes in two different intra- and extra-abdominal rat models of unilateral cryptorchidism. Br J Urol. 1998;82(4):574-7.

44. Tsounapi $\mathrm{P}$, Honda M, Dimitriadis $F$, Shimizu S, Iguchi M, Imanishi M, et al. Unilateral cryptorchidism induces testicular cells' DNA oxidative damage and apoptosis bilaterally in the rat; the effects of antioxidants administration. Eur Urol Suppl. 2015;14/2:e176.

45. Moretti E, Di Cairano G, Capitani S, Scapigliati G, Baccetti B, Collodel G, Cryptorchidism and semen quality: a TEM and molecular study. J Androl. 2007;28(1):194-9.

46. Chaki SP, Misro MM, Ghosh D, Gautam DK, Srinivas M. Apoptosis and cell removal in the cryptorchid rat testis. Apoptosis. 2005;10(2):395-405.

47. Durairajanayagam D, Agarwal A, Ong C. Causes, effects and molecular mechanisms of testicular heat stress. Reprod BioMed Online. 2015;30(1):14-27.

48. Ali Jl, Weaver DJ, Weinstein SH, Grimes EM. Scrotal temperature and semen quality in men with and without varicocele. Arch Androl. 1990;24(2):215-9.

49. Wdowiak A, Bakalczuk S, Bakalczuk G. Decreased activity of superoxide dismutase in the seminal plasma of infertile men correlates with increased sperm deoxyribonucleic acid fragmentation during the first hours after sperm donation. Andrology. 2015;3(4):748-55.

50. Banjarnahor DS, Artanti N. Antioxidant properties of flavonoids. Med J Indones. 2014;23(4):239-44.

51. Chung E, Brock GB. Cryptorchidism and its impact on male fertility: a state of art review of current literature. Can Urol Assoc J. 2011:5(3):210-4.

52. Ramaswamy S, Weinbauer GF. Endocrine control of spermatogenesis: Role of FSH and LH/testosterone. Spermatogenesis. 2014;4(2):e996025. https:// doi.org/10.1080/21565562.2014.996025.

53. Murugan V, Gulhane S, Badami S, Ramanathan M, Suresh B. Androgenic activity of the total alkaloid fraction of Alangium salviifolium (Linn. F). J Nat Med. 2002;2(1):66-70.

54. Hemalatha $\mathrm{S}$, Rajeswar $\mathrm{H}$. Fertility enhancing effect of saponin rich butanol extracts of Tribullus terrestris fruits in male albino rats. IJPCR2015. 2015;7(1):36-43.

\section{Publisher's Note}

Springer Nature remains neutral with regard to jurisdictional claims in published maps and institutional affiliations.

Ready to submit your research? Choose BMC and benefit from:

- fast, convenient online submission

- thorough peer review by experienced researchers in your field

- rapid publication on acceptance

- support for research data, including large and complex data types

- gold Open Access which fosters wider collaboration and increased citations

- maximum visibility for your research: over $100 \mathrm{M}$ website views per year

At BMC, research is always in progress.

Learn more biomedcentral.com/submissions 